\title{
The interplay between PP2A and microRNAs in leukemia
}

\author{
Peter P. Ruvolo* \\ Department of Leukemia, University of Texas MD Anderson Cancer Center, Houston, TX, USA
}

\section{Edited by: \\ Helen Chan, The Hospital for Sick \\ Children, Canada}

Reviewed by:

Olatoyosi Odenike, University of Chicago, USA

Husheng Ding, Mayo Clinic, USA

\section{*Correspondence:}

Peter P. Ruvolo, Department of Leukemia, University of Texas MD Anderson Cancer Center, 1515 Holcombe Blvd, Unit 0425, Houston, TX 77030, USA

e-mail:pruvolo@mdanderson.org
Protein phosphatase 2A (PP2A) is a serine/threonine phosphatase family whose members have been implicated in tumor suppression in many cancer models. In many cancers, loss of PP2A activity has been associated with tumorigenesis and drug resistance. Loss of PP2A results in failure to turn off survival signaling cascades that drive drug resistance such as those regulated by protein kinase B. PP2A is responsible for modulating function and controlling expression of tumor suppressors such as p53 and oncogenes such as BCL2 and MYC. Thus, PP2A has diverse functions regulating cell survival. The importance of microRNAs (miRs) is emerging in cancer biology. A role for miR regulation of PP2A is not well understood; however, recent studies suggest a number of clinically significant miRs such as miR-155 and miR-19 may include PP2A targets. We have recently found that a PP2A B subunit (B55 $\alpha$ ) can regulate a number of miRs in acute myeloid leukemia cells. The identification of a miR/PP2A axis represents a novel regulatory pathway in cellular homeostasis. The ability of miRs to suppress specific PP2A targets and for PP2A to control such miRs can add an extra level of control in signaling that could be used as a rheostat for many signaling cascades that maintain cellular homeostasis. As such, loss of PP2A or expression of miRs relevant for PP2A function could promote tumorigenesis or at least result in drug resistance. In this review, we will cover the current state of miR regulation of PP2A with a focus on leukemia. We will also briefly discuss what is known of PP2A regulation of miR expression.

\section{Keywords: PP2A, microRNA, leukemia, signal transduction, AKT}

\section{INTRODUCTION}

The cellular signaling pathways that control cellular homeostasis are complex and involve a diversity of activators and suppressors. As signal transduction is a dynamic process, the elements involved in turning off kinases are just as important as those that activate the signaling cascade. Protein phosphatase 2A (PP2A) is thought of as a global negative regulator of signaling. In reality, PP2A is not a single enzyme but rather a family of protein phosphatases that vary in the substrates they target, in the cell types where they are expressed, in the cellular compartments where they are found, and how they are regulated (1-5). The diversity of function lies in the PP2A structure. The enzyme is a heterotrimer that consists of a catalytic core that is responsible for the dephosphorylation event as well as a regulatory subunit that controls substrate specificity and cellular localization. The catalytic core is comprised of the catalytic $\mathrm{C}$ subunit which has two isoforms [PPP2RCA aka $\mathrm{C} \alpha$ and PPP2CB aka C $\beta$; Ref. (6)] and the scaffold A subunit which also has two isoforms [PPP2R1A aka A $\alpha$ and PPP2R1B aka $A \beta$; Ref. (7)]. Each isoform is located on a separate chromosome in humans. Though for both A and C subunits the isoforms are $>80 \%$ homologous by protein sequence, there are distinct differences between each isoform $(6,7)$. Thus, there are four different catalytic cores that could influence PP2A activity. The B regulatory subunit determines the substrate specificity and cellular localization of the resulting PP2A isoform. There are at present at least 17 different $B$ subunit proteins that are members of at least three families [i.e., PR55/B; PR61/B'; and PR72/B"'; Ref. (1-4)]. PP2A is an obligate heterotrimer so monomeric B subunits are degraded $(8,9)$. Modification of components of the catalytic core influences binding affinity of the B subunits and thus modulates PP2A function (1). Furthermore, post-translational modification of $B$ subunits can affect sub-cellular localization of the PP2A isoform and influence, which proteins are targeted. We have found the B56 $\alpha$ subunit (PPP2R5A) when phosphorylated at serine 28 re-localizes from the nucleus to the mitochondria (10). While nuclear B56 $\alpha$ likely supports survival signaling, in the mitochondria the B subunit dephosphorylates and inactivates BCL2 to support pro-death function. Depending on phosphorylation status, the PP2A isoform with B56 $\alpha$ can either support or impede survival (10). Thus, cell growth and survival of any given cell depends on it having the appropriate PP2A isoform(s) in place (with the required subunit modifications) to regulate the signaling cascades that are critical for its cell type. In cell that fails to express the PP2A isoforms required for its cell type, it is plausible that the result would be aberrant activation of any number of signal cascades that promotes tumorigenesis or supports drug resistance in the malignant cells.

Suppression of the PP2A family to promote global activation of cellular kinases can be achieved by targeting the catalytic core. Mechanisms include post-translational modification to inactivate protein phosphatase function [e.g., phosphorylation or methylation of the catalytic subunit; Ref. (11-13)], involvement of viral inhibitors like the SV40 small $\mathrm{T}$ antigen (14-17), or activation of cellular inhibitors such as SET or CIP2A, the former of which is induced by BCR-ABL in chronic myeloid leukemia 
[CML; (18-23)]. PP2A can be inactivated by genetic means as well. Mutation of PP2A subunits have been reported with the best characterized so far being those found in the $A \alpha$ and $A \beta$ isoforms $(24,25)$. Also, chromosome deletion or translocation containing PP2A subunits have been identified. The $5 \mathrm{q}$ deletion can include catalytic $\mathrm{C} \alpha$ subunit and loss of this PP2A subunit has been suggested to be important in myelodysplastic syndrome (MDS) as determined by the List Laboratory $(26,27)$. The topics of genetic and post-translational control of PP2A and role of SET and CIP2A are covered elsewhere in this Research Topics series. This review will focus on the emerging role of microRNAs (miRs) to regulate PP2A and will also include how at least one PP2A isoform has been shown to regulate miR expression. The interplay between the protein phosphatases and miRs suggest an elaborate feedback mechanism exists to serve as an extra level of control for signal transduction.

\section{PP2A IN ROLE IN LEUKEMIA}

We have some knowledge of PP2A role in CML and Philadelphia chromosome positive acute lymphoblastic leukemia (Ph+ ALL) thanks in large part to the work of the Perrotti group in their studies on $\mathrm{BCR}-\mathrm{ABL}$ regulation of $\mathrm{PP} 2 \mathrm{~A}$ in these diseases (18-23). In $\mathrm{CML}$, activation of $\mathrm{PP} 2 \mathrm{~A}$ is an important part of the mechanism of killing the malignant cells. Furthermore, activation of PP2A by FTY-720 or like drugs has anti-leukemic properties including for acute myeloid leukemia (AML) cells (18-21). Still, little is known about the role of PP2A in leukemia and other hematologic malignancies at present. AML remains a highly fatal disease despite our best efforts to develop novel therapies. Strategies to design tailored therapy have been in vogue but a problem arises that AML patients with the poorest outcome likely have multiple survival kinase cascades activated. Kornblau and colleagues reported that simultaneous activation of protein kinase $\mathrm{B}(\mathrm{AKT})$, protein kinase $\mathrm{C} \alpha(\mathrm{PKC} \alpha)$, and extracellular signal regulated kinase (ERK) is very detrimental to the AML patient (28). Up to $80 \%$ of AML patients have phosphorylated AKT and activation of the kinase is associated with poor prognosis (29-31). Mutations of upstream AKT signaling activators such as Fms-related tyrosine kinase (FLT3), cKIT, or RAS are found in AML patients (29-31). Targeting mutated enzymes like FLT3 could suppress the aberrant induction of AKT. Though mutation of receptor tyrosine kinases (RTK) like FLT3 has been suggested to be essential for AML, the recent report in Cell from Welch and colleagues on genomic screening of mutations in AML indicate that less than half of AML patients have a RTK mutation suggesting that other mechanisms are necessary to activate leukemic signaling pathways (32). Gallay and colleagues determined that reduced PP2A activity was associated with increased phosphorylation of AKT in AML patient samples (33). The Odero Laboratory in Spain has done extensive studies of PP2A and SET in AML (34-36). They determined that elevated SETBP1 (which stabilizes SET and supports suppression of PP2A) was associated with poor survival outcome in AML patients (34). Like Gally et al. (33), they found that PP2A activity was reduced in AML patient samples and suppressed activity of the protein phosphatase likely involved multiple mechanisms including phosphorylation of the $\mathrm{C}$ subunit, inhibition by SET or CIP2A, or dysregulation of subunit expression (35). Our own work has determined that suppressed expression of a specific B subunit, B555 $\alpha$, is critical in AML patients resulting in shorter remission duration and increased activation of AKT and PKC $\alpha(37,38)$. PP2A in acute lymphoid leukemia has not been studied as well in the clinical setting but pre-clinical models suggest that the protein phosphatase family is important in regulation of apoptosis via BCL2 and NOTCH pathways (10, 39-41).

\section{THE ROLE OF miRs IN LEUKEMIA}

The discovery of miRs was made in C. elegans in 1993 when the lin-4 gene product was identified as a RNA product that was complimentary to the lin-14 gene (42). In 2002, George Calin with Carlo Croce discovered that the 13q14 deletions found in chronic lymphoblastic leukemia (CLL) resulted in loss of miR-15 and miR16 , resulting in over expression of anti-apoptotic proteins such as BCL2 (43). An explosion of studies have occurred linking expression of a wide variety of miRs to various cancers [reviewed in Ref. (44-46)]. The role of miRs in cancer has proven to be complex. miRs can either act as tumor suppressors or tumor promoters depending on their targets (44-46). For instance, the let-7 family of miRs tends to act as tumor suppressors by targeting a number of pro-survival molecules such as RAS, BCL-X $\mathrm{X}_{\mathrm{L}}$, and MYC (4649). Recent work from the Andreeff Laboratory identified a novel mechanism for the chemokine receptor CXCR4 in the regulation of let-7 (50). In leukemia, a number of miRs have been identified that are important in leukemia cell biology and drug resistance (51-58). Some of these miRs, like miR-15, are tumor suppressors that are reduced or lost in cancer cells. miRs play a critical role in cell differentiation. There has been intensive investigation of miR-155 in a variety of leukemias (59-63). The Baltimore group found that overexpression of miR-155 in murine hematopoietic stem cells resulted in altered hematopoiesis skewing toward granulocyte/macrophage population and mice exhibited features of myeloid neoplasia (59). Importantly, the miR was found to target a number of genes that regulate myeloid differentiation including PU.1. In that and subsequent studies, miR-155 was found to be associated with poor survival outcome in AML patients (59, $61,62)$. miR-181 family members, on the other hand, support myeloid differentiation by targeting homeobox (HOX) genes such as HOXA9 and other myeloid regulatory genes $(64,65)$. While still the role of many miRs in leukemia remains unknown, a growing number of these ncRNAs are clearly important in leukemia biology and may be considered for targeting in future therapeutic strategies.

\section{miR REGULATION OF PP2A SUBUNITS}

The $\mathrm{B}$ subunit regulation mechanism best studied is the one involving proteolytic control. Alternative mechanisms could include regulation of PP2A genes by transcription factors or miRs. A comprehensive study of the A $\alpha$ gene was done by Chen and colleagues and identified a number of transcription factors including SP-1 that control expression of the scaffold gene (66). In hepatocellular carcinoma (HCC), a single nucleotide polymorphism (SNP) mutation in the PP2A A $\alpha$ promoter affects regulation by NF $\kappa \mathrm{B}$ (67). The study found that individuals from Southern China with the SNP (rs11453459) were less likely to develop HCC as these individuals exhibited greater expression of the PP2A scaffold gene 
mediated by NF $\kappa \mathrm{B}(67)$. Other examples of gene regulation of PP2A subunits include Ikaros suppression of transcription of the $\mathrm{C} \alpha$ subunit (68). Unfortunately, little is known of how PP2A B subunit genes are transcribed.

There is an ongoing effort to characterize the regulation of PP2A subunit gene expression by miRs (69-80). miRs that have been identified as suppressors of PP2A subunit expression are listed in Table 1 and depicted in Figure 1. Also included in Table 1 and Figure 1 are miRs that have been found to target SET and CIP2A as suppression of these PP2A inhibitors would allow for full and potent PP2A activity $(81,82)$. Regulation of B55 $\alpha$ by miR222 may be important in leukemia as this miR is elevated in MDS patients and the levels of the miR were even higher in patients that progressed to AML (58). Effects on differentiation may be important as many miRs including miR-222 regulate myeloid differentiation (83-86). In addition, miR-222 has been found to be overexpressed in some groups of AML patients and CLL patients with refractory disease $(56,87)$. NOTCH regulation of miR-19 is critical for T-ALL leukemogenesis and one of the critical targets is B56ع (77). Suppression of B56ع has been shown to be important in AML (36), though the significance of miR-19 in AML has yet to be determined. A lymphoma study revealed that miR-135 targets include B56 $\gamma$ (80). This B subunit is a regulator of p53 and mutations of B56 $\gamma$ have been identified in a number of solid tumor derived cell lines (88). While it is not known if miR-135b is important in leukemia, the miR has been shown to be up-regulated during megakaryocyte differentiation, so the miR plays a role in the biology of at least some hematopoietic cells (85). A greater understanding of the role for miRs in regulating PP2A will be vital to further our understanding of signal transduction control in leukemia and other cancers.

Table 1 | List of miRs reported that regulate PP2A subunit or regulators.

\begin{tabular}{|c|c|c|c|}
\hline $\begin{array}{l}\text { PP2A subunit } \\
\text { or regulator }\end{array}$ & $\begin{array}{l}\text { miR } \\
\text { identified }\end{array}$ & $\begin{array}{l}\text { Cancer or disease } \\
\text { involved }\end{array}$ & Reference \\
\hline $\mathrm{C} \alpha(\mathrm{PPP} 2 \mathrm{CA})$ & miR-520h & $\begin{array}{l}\text { Breast cancer } \\
\text { Cervical cancer }\end{array}$ & $(69,70)$ \\
\hline $\mathrm{A} \beta(\mathrm{PPP} 2 \mathrm{R} 1 \mathrm{~B})$ & miR-200c & Esophageal cancer & $(71)$ \\
\hline $\mathrm{B} 55 \alpha(\mathrm{PPP} 2 \mathrm{R} 2 \mathrm{~A})$ & miR-222 & Hepatocellular carcinoma & $(72)$ \\
\hline $\mathrm{B} 55 \alpha(\mathrm{PPP} 2 \mathrm{R} 2 \mathrm{~A})$ & miR-222 & Lung cancer & $(73)$ \\
\hline $\mathrm{B} 55 \alpha(\mathrm{PPP} 2 \mathrm{R} 2 \mathrm{~A})$ & miR-31 & Lung cancer & $(74)$ \\
\hline B56 $\alpha$ (PPP2R5A) & miR-1 & Heart disease & $(75)$ \\
\hline B56 $\alpha$ (PPP2R5A) & miR-155 & $\begin{array}{l}\text { Infection (macrophage } \\
\text { response to bacteria) }\end{array}$ & $(76)$ \\
\hline B56ع (PPP2R5E) & miR-19a & $\begin{array}{l}\text { Acute lymphoblastic } \\
\text { leukemia }\end{array}$ & $(77,78)$ \\
\hline B56ع (PPP2R5E) & miR-23a & Gastric cancer & $(79)$ \\
\hline $\mathrm{B} 56 \gamma(\mathrm{PPP} 2 \mathrm{R} 5 \mathrm{C})$ & miR-135 & Lymphoma & $(80)$ \\
\hline SET & miR-199b & Choriocarcinoma & (81) \\
\hline CIP2A & miR-375 & Oral cancer & (82) \\
\hline
\end{tabular}

Listed are reported miRs that target the PP2A catalytic core subunits $A$ and $C$, various regulatory $B$ subunits, and cellular inhibitors SET and CIP2A. Cancer or disease state associated with each report is listed.

\section{NOVEL FEEDBACK LOOPS FOR SIGNAL TRANSDUCTION: POSSIBLE ROLE FOR miRs AND PP2A}

It has been demonstrated that miR-29a is critical for myeloid differentiation and the miR has been shown to be reduced in AML $(88,89)$. Gong and colleagues recently identified a feedback loop involving the miR-29 family members, AKT2, and MYC (88). The authors found that miR-29 targets AKT which could contribute to the miR's tumor suppressor activity in AML. Consentient with a role for MYC as a negative regulator of miR-29a, over expression of MYC in AML-derived cell lines resulted in suppression of miR-29a with induction of AKT2 expression while introduction of miR-29a into cells blocked MYC expression and AKT2 levels were reduced. AKT regulation of MYC is likely via suppression of AKT which regulates MYC proteolysis. However, AKT has been shown to support expression of the PP2A B subunit (i.e., B56 $\alpha$ ) that negatively regulates MYC $(10,90,91)$. Thus, an elaborate feedback mechanism to regulate AKT signaling could be mediated by interplay between miR-29a, MYC, and PP2A. To further complicate matters, miR-155 has been identified as an important tumor promoter in AML, high risk MDS, and CLL (61-63, 92-94). One of the targets associated with miR-155 is SHIP 1, a member of the inositol polyphosphate5 -phosphatase family $(63,94)$. As SHIP 1 is a negative regulator of AKT, suppression of the phosphatase would result in activation of AKT. As miR-155 has been shown to be a prognostic factor for cytogenetic normal AML patients (62), it would be plausible that miR-155 suppression of SHIP 1 could promote signaling in patients that would likely lack activating mutations. Interestingly, miR-155 has now been shown to target B56 $\alpha$ (76). Thus, we have another layer of complexity in the putative miR/PP2A regulatory axis to control AKT in leukemia cells. A hypothetical model is depicted in Figure 2. Though quite complex, the possible feedback regulatory mechanism could be necessary for controlling cell fate and dysregulation could ultimately contribute to leukemogenesis and/or drug resistance.

\section{PP2A, miRs, AND CANCER STEM CELLS}

A study by Yoon and colleagues using human embryonic stem cells (hESC) demonstrated that (a) PP2A activity increases with concomitant increase in $\mathrm{A}$ and $\mathrm{C}$ subunit expression in differentiating hESC, (b) introduction of catalytic $\mathrm{C}$ subunit into hESC or activation of PP2A using C2-ceramide was shown to induce hESC differentiation, (c) hESC self-renewal is maintained in the presence of the PP2A inhibitor okadaic acid, and (d) suppression of PP2A C subunit expression by siRNA-induced stem cell genes such as OCT-4 and Nanog (95). The study found that stabilization of MYC and activation of AKT was important in maintenance of the hESC. Considering the importance of MYC $(96)$ and AKT $(30,31)$ in leukemic stem cells, it is plausible that PP2A regulation of both these molecules is important in maintenance of leukemia stem cells (LSC). At present, it is unknown if miRs play a role in regulating PP2A activity in normal or cancer stem cells. An interesting possibility emerges that the $\mathrm{C} \alpha$ subunit of PP2A and miR-520h could be involved in this process. Su and colleagues recently demonstrated that miR-520h suppression of the PP2A C $\alpha$ subunit was critical for promoting tumor survival and metastasis of breast cancer and cervical cancer cells $(69,70)$. The adenovirus type 5 E1A protein was found to act as a tumor suppressor by inhibiting miR-520h 


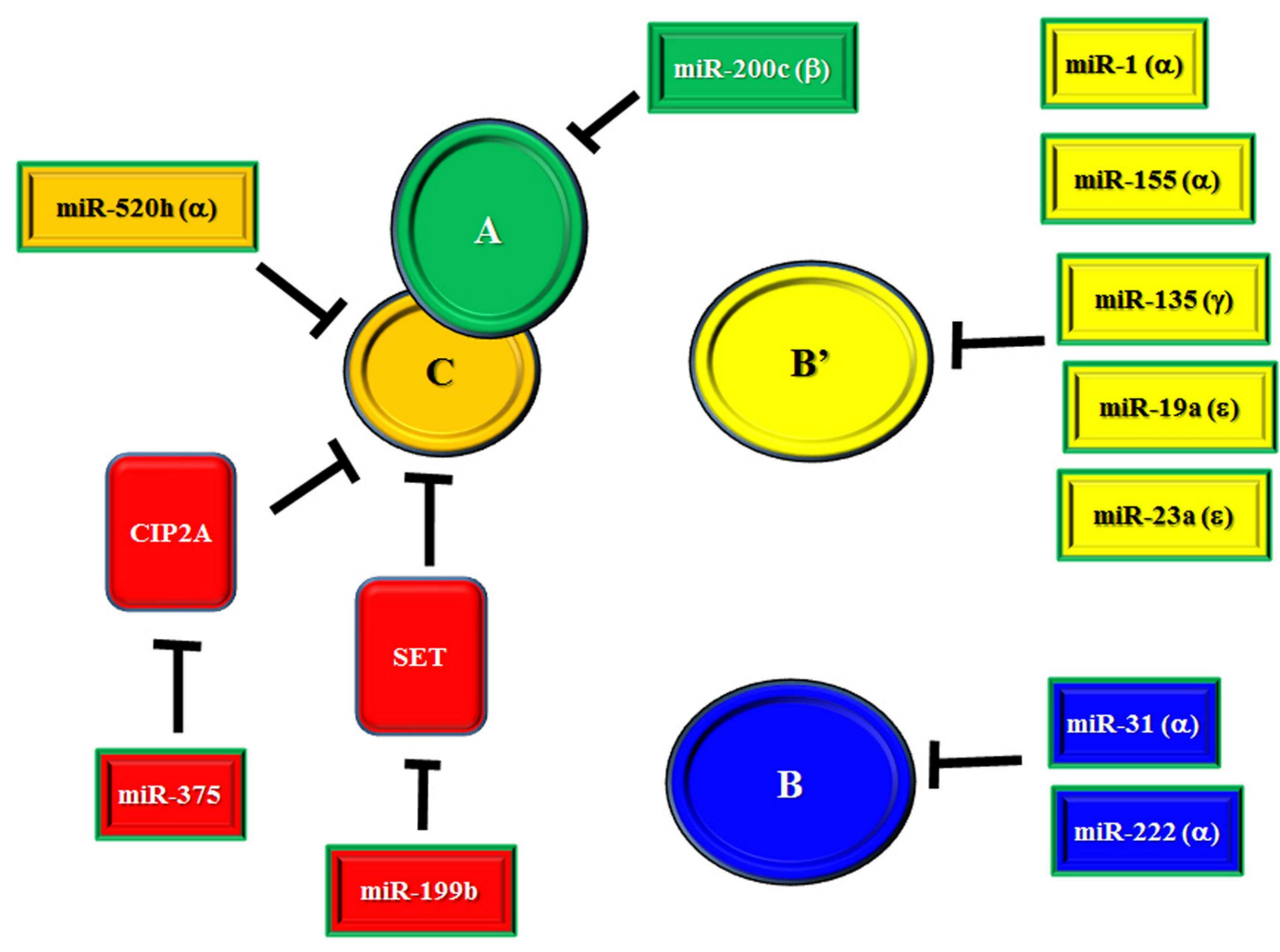

FIGURE 1 | miR regulation of PP2A and PP2A inhibitors. Depicted in the figure are identified miRs that target the PP2A catalytic core subunits A and C, various regulatory $B$ subunits, and cellular inhibitors SET and CIP2A.

expression which resulted in activation of PP2A to suppress prosurvival functions of NF $\kappa \mathrm{B}$ and TWIST. Interestingly, a recent analysis of $\mathrm{miR}$ expression in hESC cell lines indicated that members of the miR-520 family were highly expressed in those cells (97). While it remains to be determined, it is plausible that suppression of PP2A in stem cells observed by Yoon and colleagues could be due to suppression of PP2A by miR-520h (95). As this miR targets a critical component of the catalytic core (i.e., $\mathrm{C} \alpha$ ) this miR could potentially suppress any number of PP2A isoforms. Another interesting possibility involves miR-200c and the PP2A A $\beta$ subunit. Recent studies have suggested that miR-200 family members are critical for maintaining stem cells [reviewed in Ref. (97-99)]. These miRs are positively regulated by MYC, OCT-4, and other stem cell transcription factors (98). The miR-200 c family member was found to suppress the PP2A A $\beta$ subunit in esophageal cancer, resulting in increased chemoresistance and induction of AKT (71). Considering the important role AKT plays in stem cells, the suppression of this PP2A subunit could be important in supporting cancer stem cells. Furthermore, blockade of one of the PP2A A scaffold subunits by a miR could be another means for suppression of PP2A function by a diverse number of PP2A isoforms. Supporting such a concept, recent work from the Perrotti group has demonstrated that activation of PP2A using FTY-720 in CML cells results in eradication of the leukemic stem cells thus the concept of $\mathrm{PP} 2 \mathrm{~A}$ regulation of stemness likely is pertinent to LSC as well (100). The role of miRs in stem cell differentiation is an active area of research but the field is just emerging. It remains to be determined if and how miRs and PP2A might interact to influence stem cell properties.

\section{B55 $\alpha$ REGULATION OF miRs IN LEUKEMIA}

We recently identified a number of miRs that were subject to regulation by the B55 $\alpha$ subunit that has been found to suppress AKT and PKC $\alpha$ survival signaling in AML cells $(37,38)$. The possible role of $\mathrm{B} 55 \alpha$ in regulating miR expression was examined as we had shown the B subunit indirectly supported expression of MYC (38). MYC is known to control a number of miRs (47, 101-103). Suppression of B55 $\alpha$ by shRNA in the AML cell line OCI-AML3 resulted in altered expression of a number of miRs. For the most part, reduction of the B subunit led to significant suppression (i.e., $>2$ fold) of over 30 miRs. This finding would be consistent with possible participation of MYC as MYC has been suggested to have a role in global repression of miRs (47). The miR most affected was miR-1260a, though not much is known about this miR. Among the other miRs that were suppressed are miR-142-3p, miR-142-5p, and miR-195-5p (38). The miR-142 members have been shown to be mutated in lymphoma and AML and thus are of interest to those studying hematologic malignancies $(103,104)$. Relevant for myeloid leukemia, miR-142-3p has been implicated in control of myeloid differentiation (83). With MYC reduction in the AML cells with reduced B55 $\alpha$, expression of the more prominent MYC targets including those in miR 17-92 cluster were not strongly 


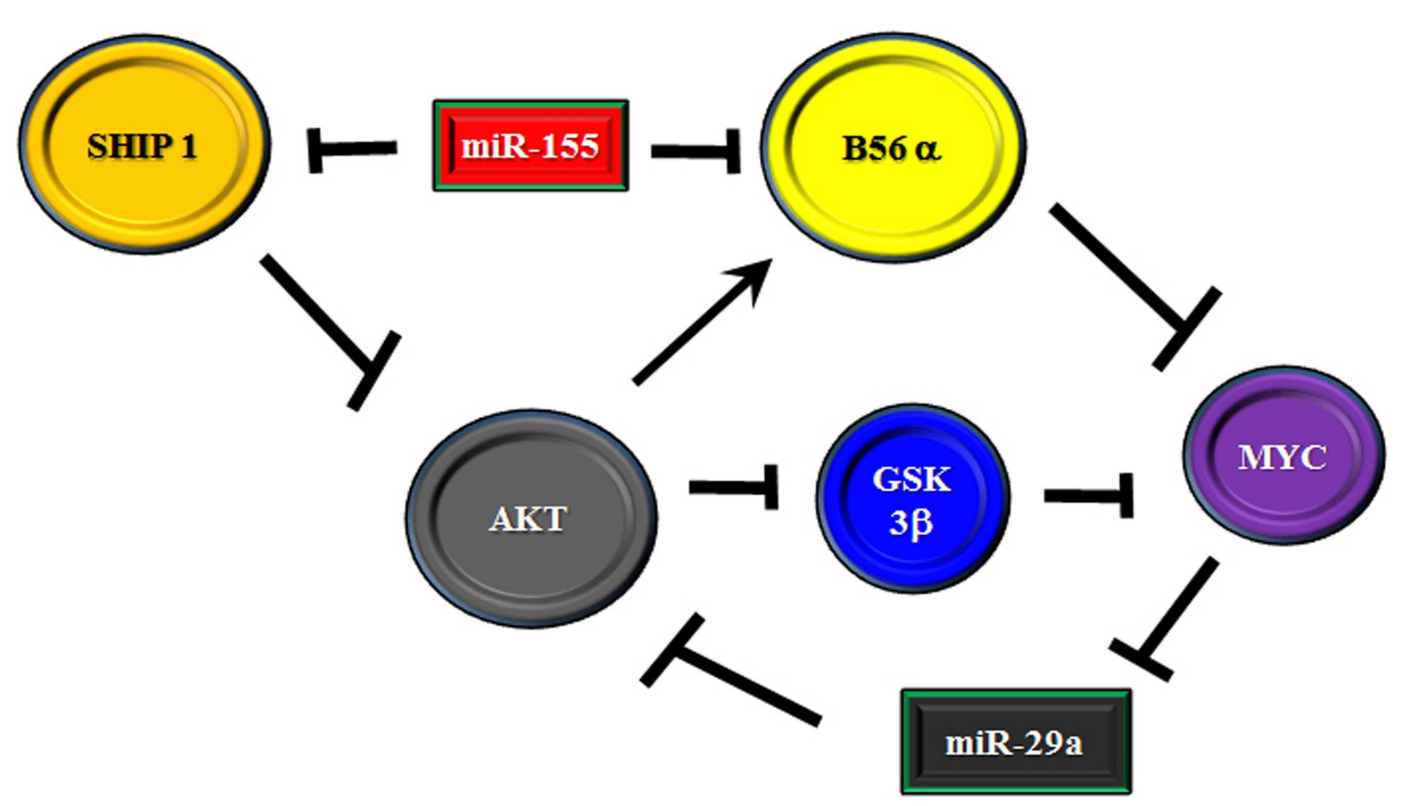

FIGURE 2 | Model of feedback loop in B56 $\alpha /$ AKT/MYC axis involving miRs. Model is presented where the B56 $\alpha$ PP2A subunit and PTEN are negatively regulated by miR-155. The miR may act as a rheostat for AKT signaling as one the one hand PTEN suppression activates AKT but the
miR also suppresses the $B$ subunit which is positively regulated by AKT. The B subunit negatively regulates MYC and MYC supports expression of AKT targeting miR-29 so another layer of feedback may exist via MYC/miR-29.

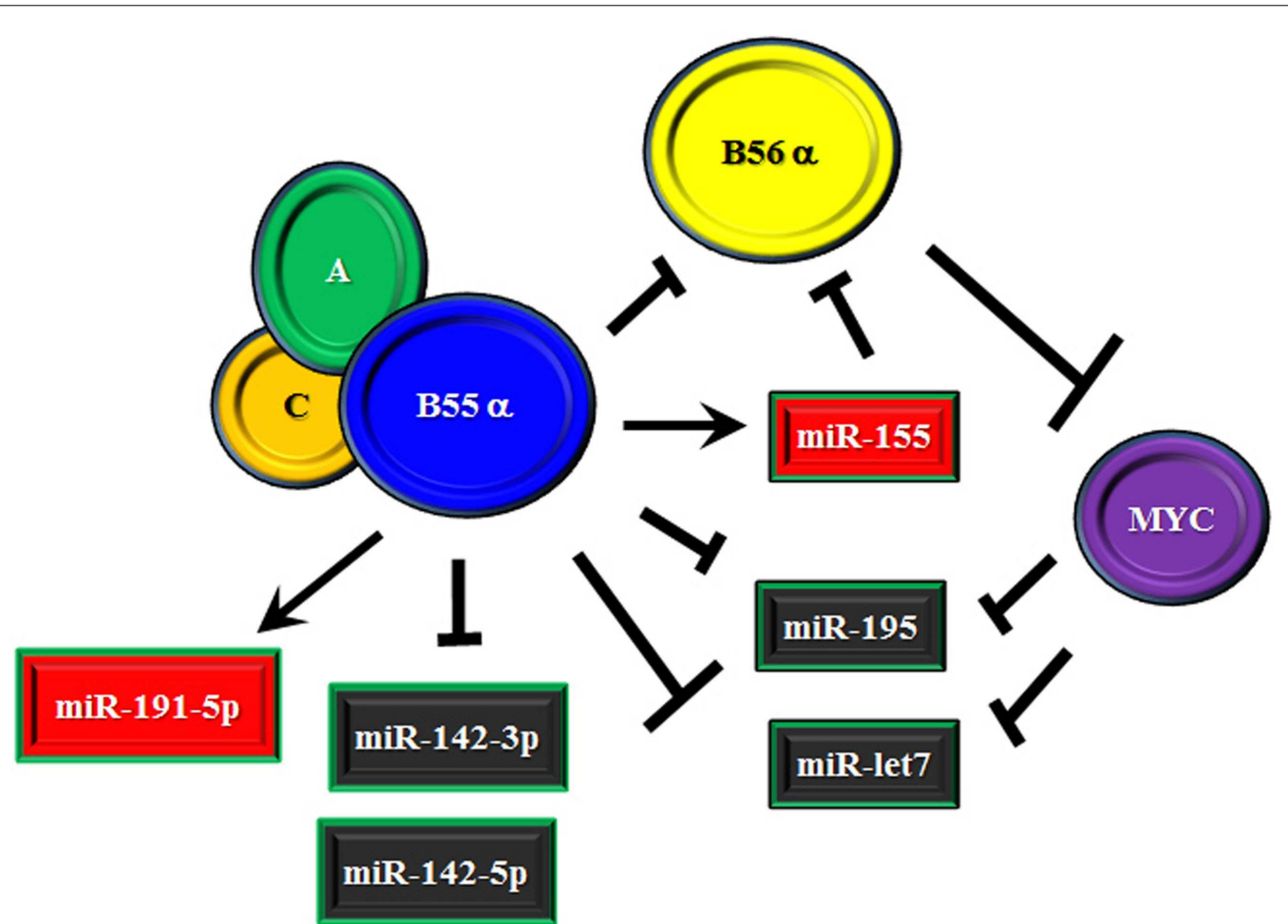

FIGURE 3 | Model of effect of B55 $\alpha / B 56 \alpha$ competition on miR expression. Model is presented where the B55 $\alpha$ and B56 $\alpha$ PP2A subunits compete, resulting in additional regulation mediated by miRs. $B 55 \alpha$ supports miR-155 which targets B56 $\alpha$ so an additional level of suppression exists in the competition between the two B subunits. B56 $\alpha$ may have pro-survival function by suppressing $B 55 \alpha$ mediated expression of miR-191 and/or allowing expression of the miR-142 members, which are inhibited by $\mathrm{B} 55 \alpha$. 
affected (38). However, induction of miR-195 observed in the cells could be mediated by MYC. MYC has been shown to regulate a number of miRs including miR-195 and it has been suggested that repression of anti-tumor miRs may be critical to MYC's oncogenic activity (47). While it is not clear the role of miR-195 in leukemia, the miR has been implicated as a tumor suppressor in a number of solid tumor models (105). Targets of miR-195 include cyclins and cyclin dependent kinases (106), MYB (107), and NF $\kappa \mathrm{B}$ signaling via IKK $\alpha$ and TAB3 (108). One of the miR-195 targets is the RET tyrosine kinase so perhaps inhibition of this kinase may be important in leukemia (109). Of the miRs elevated in response to suppression of B55 $\alpha$ in the AML cells was miR-191-5p and miR-155 (38). The miR-191-5p has been implicated as being detrimental for patient survival in AML (89). As discussed earlier, a critical miR in leukemia and other cancers is miR-155. Interestingly, miR-155 has been shown to target B56 $\alpha$ in macrophages (76). This finding and the possibility that B55 $\alpha$ supports miR-155 expression suggests a complex regulatory mechanism whereby the B55 subunit can suppress the B56 subunit by competition for the catalytic core and by inducing a miR that targets that competing $\mathrm{B}$ subunit (depicted in Figure 3). This regulatory model is currently under investigation in our laboratory.

\section{CONCLUSION}

The role of miRs as regulators of $\mathrm{PP} 2 \mathrm{~A}$ and possible control of miR expression by $\mathrm{PP} 2 \mathrm{~A}$ isoforms is only just emerging. Publications covering miR control of $\mathrm{PP} 2 \mathrm{~A}$ subunits and regulators of $\mathrm{PP} 2 \mathrm{~A}$ (e.g., SET and CIP2A) are just emerging. Recent studies suggest that miR control of the PP2A genes is important as results indicate that dysregulation of PP2A targeting miRs can result in induction of signaling pathways associated with the particular PP2A isoform. An example of such a finding involves activation of AKT when miR-222 (which targets the B55 $\alpha$ subunit) is elevated (72). The recent finding that miR-155 target genes include a PP2A subunit [i.e., B56 $\alpha$; Ref. (76)] raises the possibility that part of the tumor support properties of this miR may involve suppression of the B subunit. A link between miR-155 and B56 $\alpha$ in leukemia cells remains to be established. Surprisingly, the regulation of miRs by PP2A has been less well studied. The well documented relationship between MYC and PP2A would suggest that there would be PP2A regulation of at least MYC sensitive miRs. Interestingly, though B55 $\alpha$ serves to positively support MYC expression, there were no effects observed on MYC sensitive miRs in our recent study in AML (38). Still other miRs including miR-142, miR-191, and miR-155 appear to be controlled by the PP2A subunit (38). It remains to be seen how the B subunit regulates these miRs. Are specific transcription factors targeted or are effects mediated by suppression of kinases that phosphorylate transcription factors? Also, a role for other PP2A B subunits in miR regulation is presently unknown. It is likely that other B subunits will exert effects on miR expression and warrant investigation. A better understanding of how PP2A controls miRs and vice versa will provide a better understanding how survival signaling is dysregulated in leukemia and may lead to novel strategies for future therapies.

\section{ACKNOWLEDGMENTS}

This work was supported by an award from the John and Laura Arnold Foundation and The Center for Stem Cell and
Developmental Biology at University of Texas MD Anderson Cancer Center.

\section{REFERENCES}

1. Janssens V, Longin S, Goris J. PP2A holoenzyme assembly: in cauda venenum (the sting is in the tail). Trends Biochem Sci (2008) 33:113-21. doi:10.1016/j. tibs.2007.12.004

2. Janssens V, Rebollo A. The role and therapeutic potential of Ser/Thr phosphatase PP2A in apoptotic signalling networks in human cancer cells. Curr Mol Med (2012) 12:268-87. doi:10.2174/156652412799218930

3. Mumby MC, Walter G. Protein serine/threonine phosphatases: structure, regulation, and function in cell growth. Physiol Rev (1993) 73:673-99.

4. Orgad S, Brewis ND, Alphey L, Dudai Y, Cohen PT. The structure of protein phosphatase $2 \mathrm{~A}$ is as highly conserved as that of protein phosphatase 1. FEBS Lett (1990) 275:44-8. doi:10.1016/0014-5793(90)81435-Q

5. McCright B, Virshup DM. Identification of a new family of protein phosphatase 2A regulatory subunits. J Biol Chem (1995) 270:26123-8. doi:10.1074/jbc.270. 44.26123

6. Stone SR, Hofsteenge J, Hemmings BA. Molecular cloning of cDNAs encoding two isoforms of the catalytic subunit of protein phosphatase 2A. Biochemistry (1987) 26:7215-20. doi:10.1021/bi00397a003

7. Hemmings BA, Adams-Pearson C, Maurer F, Muller P, Goris J, Merlevede W, et al. Alpha and beta forms of the $65 \mathrm{kd}$ subunit of protein phosphatase $2 \mathrm{~A}$ have similar 39 amino acid repeating structure. Biochemistry (1990) 29:3166-73. doi:10.1021/bi00465a002

8. Silverstein AM, Barrow CA, Davis AJ, Mumby MC. Actions of PP2A on the MAP kinase pathway and apoptosis are mediated by distinct regulatory subunits. Proc Natl Acad Sci U S A (2002) 99:4221-6. doi:10.1073/pnas.072071699

9. Strack S, Cribbs JT, Gomez L. Critical role for protein phosphatase 2A heterotrimers in mammalian cell survival. J Biol Chem (2004) 279:47732-9. doi:10.1074/jbc.M408015200

10. Ruvolo VR, Kurinna SM, Karanjeet KB, Schuster TF, Martelli AM, McCubrey JA, et al. PKR regulates B56(alpha)-mediated BCL2 phosphatase activity in acute lymphoblastic leukemia-derived REH cells. J Biol Chem (2008) 283:35474-85. doi:10.1074/jbc.M800951200

11. Chen J, Parsons S, Brautigan DL. Tyrosine phosphorylation of protein phosphatase $2 \mathrm{~A}$ in response to growth stimulation and v-src transformation of fibroblasts. J Biol Chem (1994) 269:7957-62.

12. Vacaru AM, den Hertog J. Serine dephosphorylation of receptor protein tyrosine phosphatase alpha in mitosis induces Src binding and activation. Mol Cell Biol (2010) 30:2850-61. doi:10.1128/MCB.01202-09

13. Tolstykh T, Lee J, Vafai S, Stock JB. Carboxyl methylation regulates phosphoprotein phosphatase $2 \mathrm{~A}$ by controlling the association of regulatory $\mathrm{B}$ subunits. EMBO J (2000) 19:5682-91. doi:10.1093/emboj/19.21.5682

14. Pallas DC, Shahrik LK, Martin BL, Jaspers S, Miller TB, Brautigan DL, et al. Polyoma small and middle $\mathrm{T}$ antigens and SV40 small $\mathrm{T}$ antigen form stable complexes with protein phosphatase 2A. Cell (1990) 60:167-76. doi:10.1016/0092-8674(90)90726-U

15. Yang SI, Lickteig RL, Estes R, Rundell K, Walter G, Mumby MC. Control of protein phosphatase 2A by simian virus 40 small-T antigen. Mol Cell Biol (1991) 11:1988-95.

16. Mateer SC, Fedorov SA, Mumby MC. Identification of structural elements involved in the interaction of simian virus 40 small tumor antigen with protein phosphatase 2A. J Biol Chem (1998) 273:35339-46. doi:10.1074/jbc.273. 52.35339

17. Mullane KP, Ratnofsky M, Cullere X, Schaffhausen B. Signaling from polyomavirus middle $\mathrm{T}$ and small $\mathrm{T}$ defines different roles for protein phosphatase 2A. Mol Cell Biol (1998) 18:7556-64.

18. Neviani P, Santhanam R, Trotta R, Notari M, Blaser BW, Liu S, et al. The tumor suppressor PP2A is functionally inactivated in blast crisis CML through the inhibitory activity of the BCR/ABL-regulated SET protein. Cancer Cell (2005) 8:355-68. doi:10.1016/j.ccr.2005.10.015

19. Perrotti D, Neviani P. ReSETting PP2A tumour suppressor activity in blast crisis and imatinib-resistant chronic myelogenous leukaemia. Br J Cancer (2006) 95:775-81. doi:10.1038/sj.bjc.6603317

20. Neviani P, Santhanam R, Oaks JJ, Eiring AM, Notari M, Blaser BW, et al. FTY720, a new alternative for treating blast crisis chronic myelogenous leukemia and Philadelphia chromosome-positive acute lymphocytic leukemia. J Clin Invest (2007) 117:2408-21. doi:10.1172/JCI31095 
21. Yang Y, Huang Q, Lu Y, Li X, Huang S. Reactivating PP2A by FTY720 as a novel therapy for AML with C-KIT tyrosine kinase domain mutation. J Cell Biochem (2012) 113:1314-22. doi:10.1002/jcb.24003

22. Perrotti D, Neviani P. Protein phosphatase 2A (PP2A), a drugable tumor suppressor in Ph1(+) leukemias. Cancer Metastasis Rev (2008) 27:159-68. doi:10.1007/s10555-008-9119-x

23. Perrotti D, Neviani P. Protein phosphatase 2A: a target for anticancer therapy. Lancet Oncol (2013) 14:e229-38. doi:10.1016/S1470-2045(12)70558-2

24. Calin GA, di Iasio MG, Caprini E, Vorechovsky I, Natali PG, Sozzi G, et al. Low frequency of alterations of the alpha (PPP2R1A) and beta (PPP2R1B) isoforms of the subunit A of the serine-threonine phosphatase $2 \mathrm{~A}$ in human neoplasms. Oncogene (2000) 19:1191-5. doi:10.1038/sj.onc.1203389

25. Wang SS, Esplin ED, Li JL, Huang L, Gazdar A, Minna J, et al. Alterations of the PPP2R1B gene in human lung and colon cancer. Science (1998) 282:284-7. doi:10.1126/science.282.5387.284

26. Wei S, Chen X, Rocha K, Epling-Burnette PK, Djeu JY, Liu Q, et al. A critical role for phosphatase haplodeficiency in the selective suppression of deletion 5q MDS by lenalidomide. Proc Natl Acad Sci U S A (2009) 106:12974-9. doi:10.1073/pnas.0811267106

27. Giagounidis A, Mufti GJ, Fenaux P, Germing U, List A, MacBeth KJ. Lenalidomide as a disease-modifying agent in patients with $\operatorname{del}(5 \mathrm{q})$ myelodysplastic syndromes: linking mechanism of action to clinical outcomes. Ann Hematol (2014) 93:1-11. doi:10.1007/s00277-013-1863-5

28. Kornblau SM, Womble M, Qiu YH, Jackson CE, Chen W, Konopleva M, et al. Simultaneous activation of multiple signal transduction pathways confers poor prognosis in acute myelogenous leukemia. Blood (2006) 108:2358-65. doi:10.1182/blood-2006-02-003475

29. Scholl C, Gilliland DG, Fröhling S. Deregulation of signaling pathways in acute myeloid leukemia. Semin Oncol (2008) 35:336-45. doi:10.1053/j.seminoncol. 2008.04.004

30. Martelli AM, Evangelisti C, Chiarini F, McCubrey JA. The phosphatidylinositol 3-kinase/Akt/mTOR signaling network as a therapeutic target in acute myelogenous leukemia patients. Oncotarget (2010) 1:89-103.

31. McCubrey JA, Steelman LS, Chappell WH, Abrams SL, Montalto G, Cervello M, et al. Mutations and deregulation of Ras/Raf/MEK/ERK and PI3K/PTEN/Akt/mTOR cascades. Oncotarget (2012) 3:954-87.

32. Welch JS, Ley TJ, Link DC, Miller CA, Larson DE, Koboldt DC, et al. The origin and evolution of mutations in acute myeloid leukemia. Cell (2012) 150:264-78. doi:10.1016/j.cell.2012.06.023

33. Gallay N, Dos Santos C, Cuzin L, Bousquet M, Simmonet Gouy V, Chaussade $\mathrm{C}$, et al. The level of AKT phosphorylation on threonine 308 but not on serine 473 is associated with high-risk cytogenetics and predicts poor overall survival in acute myeloid leukaemia. Leukemia (2009) 23:1029-38. doi:10.1038/leu.2008.395

34. Cristóbal I, Blanco FJ, Garcia-Orti L, Marcotegui N, Vicente C, Rifon J, et al. SETBP1 overexpression is a novel leukemogenic mechanism that predicts adverse outcome in elderly patients with acute myeloid leukemia. Blood (2010) 115:615-25. doi:10.1182/blood-2009-06-227363

35. Cristóbal I, Garcia-Orti L, Cirauqui C, Alonso MM, Calasanz MJ, Odero MD. PP2A impaired activity is a common event in acute myeloid leukemia and its activation by forskolin has a potent anti-leukemic effect. Leukemia (2011) 25:606-14. doi:10.1038/leu.2010.294

36. Cristóbal I, Cirauqui C, Castello-Cros R, Garcia-Orti L, Calasanz MJ, Odero MD. Downregulation of PPP2R5E is a common event in acute myeloid leukemia that affects the oncogenic potential of leukemic cells. Haematologica (2013) 98:e103-14. doi:10.3324/haematol.2013.084731

37. Ruvolo PP, Qui YH, Coombes KR, Zhang N, Ruvolo VR, Borthakur G, et al. Low expression of PP2A regulatory subunit B55alpha is associated with T308 phosphorylation of AKT and shorter complete remission duration in acute myeloid leukemia patients. Leukemia (2011) 25:1711-7. doi:10.1038/leu.2011.146

38. Ruvolo PP, Ruvolo VR, Jacamo R, Burks JK, Zeng Z, Duvvuri SR, et al. The protein phosphatase $2 \mathrm{~A}$ regulatory subunit $\mathrm{B} 55 \alpha$ is a modulator of signaling and microRNA expression in acute myeloid leukemia cells. Biochim Biophys Acta (2014) 1843:1969-77. doi:10.1016/j.bbamcr.2014.05.006

39. Hales EC, Orr SM, Larson Gedman A, Taub JW, Matherly LH. Notch1 receptor regulates AKT protein activation loop (Thr308) dephosphorylation through modulation of the PP2A phosphatase in phosphatase and tensin homolog (PTEN)-null T-cell acute lymphoblastic leukemia cells. J Biol Chem (2013) 288:22836-48. doi:10.1074/jbc.M113.451625
40. Blalock WL, Grimaldi C, Fala F, Follo M, Horn S, Basecke J, et al. PKR activity is required for acute leukemic cell maintenance and growth: a role for PKR-mediated phosphatase activity to regulate GSK-3 phosphorylation. J Cell Physiol (2009) 221:232-41. doi:10.1002/jcp.21848

41. Gutierrez A, Pan L, Groen RW, Baleydier F, Kentsis A, Marineau J, et al. Phenothiazines induce PP2A-mediated apoptosis in T cell acute lymphoblastic leukemia. J Clin Invest (2014) 124:644-55. doi:10.1172/JCI65093

42. Lee RC, Feinbaum RL, Ambros V. The C. elegans heterochronic gene lin-4 encodes small RNAs with antisense complementarity to lin-14. Cell (1993) 75:843-54. doi:10.1016/0092-8674(93)90529-Y

43. Calin GA, Dumitru CD, Shimizu M, Bichi R, Zupo S, Noch E, et al. Frequent deletions and down-regulation of micro-RNA genes miR15 and miR16 at 13q14 in chronic lymphocytic leukemia. Proc Natl Acad Sci U S A (2002) 99:15524-9. doi:10.1073/pnas.242606799

44. Kunej T, Godnic I, Horvat S, Zorc M, Calin GA. Cross talk between microRNA and coding cancer genes. Cancer J (2012) 18:223-31. doi:10.1097/PPO. 0b013e318258b771

45. Van Roosbroeck K, Pollet J, Calin GA. miRNAs and long noncoding RNAs as biomarkers in human diseases. Expert Rev Mol Diagn (2013) 13:183-204. doi:10.1586/erm.12.134

46. Gurtan AM, Sharp PA. The role of miRNAs in regulating gene expression networks. J Mol Biol (2013) 425:3582-600. doi:10.1016/j.jmb.2013.03.007

47. Chang TC, Yu D, Lee YS, Wentzel EA, Arking DE, West KM, et al. Widespread microRNA repression by Myc contributes to tumorigenesis. Nat Genet (2008) 40:43-50. doi:10.1038/ng.2007.30

48. Copley MR, Eaves CJ. Developmental changes in hematopoietic stem cell properties. Exp Mol Med (2013) 45:e55. doi:10.1038/emm.2013.98

49. Shyh-Chang N, Daley GQ. Lin28: primal regulator of growth and metabolism in stem cells. Cell Stem Cell (2013) 12:395-406. doi:10.1016/j.stem.2013. 03.005

50. Chen Y, Jacamo R, Konopleva M, Garzon R, Croce C, Andreeff M. CXCR4 downregulation of let-7a drives chemoresistance in acute myeloid leukemia. J Clin Invest (2013) 123:2395-407. doi:10.1172/JCI66553

51. Calin GA, Croce CM. MicroRNAs and chromosomal abnormalities in cancer cells. Oncogene (2006) 25:6202-10. doi:10.1038/sj.onc.1209910

52. Garzon R, Fabbri M, Cimmino A, Calin GA, Croce CM. MicroRNA expression and function in cancer. Trends Mol Med (2006) 12:580-7. doi:10.1016/j. molmed.2006.10.006

53. Marcucci G, Radmacher MD, Mrozek K, Bloomfield CD. MicroRNA expression in acute myeloid leukemia. Curr Hematol Malig Rep (2009) 4:83-8. doi:10.1007/s11899-009-0012-7

54. Aqeilan RI, Calin GA, Croce CM. miR-15a and miR-16-1 in cancer: discovery, function and future perspectives. Cell Death Differ (2010) 17:215-20. doi:10.1038/cdd.2009.69

55. Calin GA, Pekarsky Y, Croce CM. The role of microRNA and other non-coding RNA in the pathogenesis of chronic lymphocytic leukemia. Best Pract Res Clin Haematol (2007) 20:425-37. doi:10.1016/j.beha.2007.02.003

56. Wang Y, Li Z, He C, Wang D, Yuan X, Chen J, et al. MicroRNAs expression signatures are associated with lineage and survival in acute leukemias. Blood Cells Mol Dis (2010) 44:191-7. doi:10.1016/j.bcmd.2009.12.010

57. Barbarotto E, Calin GA. Potential therapeutic applications of miRNA-based technology in hematological malignancies. Curr Pharm Des (2008) 14:2040-50. doi:10.2174/138161208785294627

58. Pons A, Nomdedeu B, Navarro A, Gaya A, Gel B, Diaz T, et al. Hematopoiesisrelated microRNA expression in myelodysplastic syndromes. Leuk Lymphoma (2009) 50:1854-9. doi:10.3109/10428190903147645

59. O'Connell RM, Chaudhuri AA, Rao DS, Baltimore D. Inositol phosphatase SHIP1 is a primary target of miR-155. Proc Natl Acad Sci U S A (2009) 106:7113-8. doi:10.1073/pnas.0902636106

60. Rokah OH, Granot G, Ovcharenko A, Modai S, Pasmanik-Chor M, Toren A, et al. Downregulation of miR-31, miR-155, and miR-564 in chronic myeloid leukemia cells. PLoS One (2012) 7:e35501. doi:10.1371/journal.pone.0035501

61. Metzeler KH, Maharry K, Kohlschmidt J, Volinia S, Mrózek K, Becker H, et al. A stem cell-like gene expression signature associates with inferior outcomes and a distinct microRNA expression profile in adults with primary cytogenetically normal acute myeloid leukemia. Leukemia (2013) 27:2023-31. doi:10.1038/leu.2013.181

62. Marcucci G, Maharry KS, Metzeler KH, Volinia S, Wu YZ, Mrózek K, et al. Clinical role of microRNAs in cytogenetically normal acute myeloid leukemia: 
miR-155 upregulation independently identifies high-risk patients. J Clin Oncol (2013) 31:2086-93. doi:10.1200/JCO.2012.45.6228

63. Cui B, Chen L, Zhang S, Mraz M, Fecteau JF, Yu J, et al. MicroRNA-155 influences B-cell receptor signaling and associates with aggressive disease in chronic lymphocytic leukemia. Blood (2014) 124:546-54. doi:10.1182/blood-2014-03559690

64. Li X, Zhang J, Gao L, McClellan S, Finan MA, Butler TW, et al. miR-181 mediates cell differentiation by interrupting the Lin 28 and let-7 feedback circuit. Cell Death Differ (2012) 19:378-86. doi:10.1038/cdd.2011.127

65. Li Z, Huang H, Li Y, Jiang X, Chen P, Arnovitz S, et al. Up-regulation of a HOXA-PBX3 homeobox-gene signature following down-regulation of miR181 is associated with adverse prognosis in patients with cytogenetically abnormal AML. Blood (2012) 119:2314-24. doi:10.1182/blood-2011-10-386235

66. Chen HG, Han WJ, Deng M, Qin J, Yuan D, Liu JP, et al. Transcriptional regulation of PP2A-A alpha is mediated by multiple factors including AP-2alpha, CREB, ETS-1, and SP-1. PLoS One (2009) 4:e7019. doi:10.1371/journal.pone. 0007019

67. Chen HF, Mai JR, Wan JX, Gao YF, Lin LN, Wang SZ, et al. Role of a novel functional variant in the PPP2R1A promoter on the regulation of PP2AAalpha and the risk of hepatocellular carcinoma. PLoS One (2013) 8:e59574. doi:10.1371/journal.pone.0059574

68. Nagpal K, Watanabe KS, Tsao BP, Tsokos GC. Transcription factor Ikaros represses protein phosphatase $2 \mathrm{~A}$ ( $\mathrm{PP} 2 \mathrm{~A})$ expression through an intronic binding site. J Biol Chem (2014) 289:13751-7. doi:10.1074/jbc.M114.558197

69. Su JL, Chen PB, Chen YH, Chen SC, Chang YW, Jan YH, et al. Downregulation of microRNA miR-520h by E1A contributes to anticancer activity. Cancer Res (2010) 70:5096-108. doi:10.1158/0008-5472.CAN-09-4148

70. Yu YH, Chen HA, Chen PS, Cheng YJ, Hsu WH, Chang YW, et al. miR-520hmediated FOXC2 regulation is critical for inhibition of lung cancer progression by resveratrol. Oncogene (2013) 32:431-43. doi:10.1038/onc.2012.74

71. Hamano R, Miyata H, Yamasaki M, Kurokawa Y, Hara J, Moon JH, et al. Overexpression of miR-200c induces chemoresistance in esophageal cancers mediated through activation of the Akt signaling pathway. Clin Cancer Res (2011) 17:3029-38. doi:10.1158/1078-0432.CCR-10-2532

72. Wong QW, Ching AK, Chan AW, Choy KW, To KF, Lai PB, et al. miR222 overexpression confers cell migratory advantages in hepatocellular carcinoma through enhancing AKT signaling. Clin Cancer Res (2010) 16:867-75. doi:10.1158/1078-0432.CCR-09-1840

73. Zhang Y, Ma T, Yang S, Xia M, Xu J, An H, et al. High-mobility group Al proteins enhance the expression of the oncogenic miR-222 in lung cancer cells. Mol Cell Biochem (2011) 357:363-71. doi:10.1007/s11010-011-0907-1

74. Liu X, Sempere LF, Ouyang H, Memoli VA, Andrew AS, Luo Y, et al. MicroRNA31 functions as an oncogenic microRNA in mouse and human lung cancer cells by repressing specific tumor suppressors. J Clin Invest (2010) 120:1298-309. doi:10.1172/JCI39566

75. Belevych AE, Sansom SE, Terentyeva R, Ho HT, Nishijima Y, Martin MM, et al. MicroRNA-1 and -133 increase arrhythmogenesis in heart failure by dissociating phosphatase activity from RyR2 complex. PLoS One (2011) 6:e28324. doi:10.1371/journal.pone.0028324

76. Holla S, Kurowska-Stolarska M, Bayry J, Balaji KN. Selective inhibition of IFNG-induced autophagy by miR155- and miR31-responsive WNT5A and SHH signaling. Autophagy (2014) 10:311-30. doi:10.4161/auto.27225

77. Mavrakis KJ, Wolfe AL, Oricchio E, Palomero T, de Keersmaecker K, McJunkin $\mathrm{K}$, et al. Genome-wide RNA-mediated interference screen identifies miR-19 targets in Notch-induced T-cell acute lymphoblastic leukaemia. Nat Cell Biol (2010) 12:372-9. doi:10.1038/ncb2037

78. Hales EC, Taub JW, Matherly LH. New insights into Notch1 regulation of the PI3K-AKT-mTOR1 signaling axis: targeted therapy of $\gamma$-secretase inhibitor resistant T-cell acute lymphoblastic leukemia. Cell Signal (2014) 26:149-61. doi:10.1016/j.cellsig.2013.09.021

79. Liu X, Liu Q, Fan Y, Wang S, Liu X, Zhu L, et al. Downregulation of PPP2R5E expression by miR-23a suppresses apoptosis to facilitate the growth of gastric cancer cells. FEBS Lett (2014) 588:3160-9. doi:10.1016/j.febslet.2014. 05.068

80. Suzuki HI, Matsuyama H, Noguchi M, Yao T, Komatsu N, Mano H, et al. Computational dissection of distinct microRNA activity signatures associated with peripheral T cell lymphoma subtypes. Leukemia (2013) 27:2107-11. doi:10.1038/leu.2013.121
81. Chao A, Tsai CL, Wei PC, Hsueh S, Chao AS, Wang CJ, et al. Decreased expression of microRNA-199b increases protein levels of SET (protein phosphatase 2A inhibitor) in human choriocarcinoma. Cancer Lett (2010) 291:99-107. doi:10.1016/j.canlet.2009.10.005

82. Jung HM, Patel RS, Phillips BL, Wang H, Cohen DM, Reinhold WC, et al. Tumor suppressor miR-375 regulates MYC expression via repression of CIP2A coding sequence through multiple miRNA-mRNA interactions. Mol Biol Cell (2013) 24(1638-1648):S1-7. doi:10.1091/mbc.E12-12-0891

83. Wang XS, Gong JN, Yu J, Wang F, Zhang XH, Tan ZQ, et al. MicroRNA-29a and microRNA-142-3p are regulators of myeloid differentiation and acute myeloid leukemia. Blood (2012) 119:4992-5004. doi:10.1182/blood-2011-10-385716

84. Forrest AR, Kanamori-Katayama M, Tomaru Y, Lassmann T, Ninomiya N, Takahashi Y, et al. Induction of microRNAs, miR-155, miR-222, miR-424 and miR503 , promotes monocytic differentiation through combinatorial regulation. Leukemia (2010) 24:460-6. doi:10.1038/leu.2009.246

85. Garzon R, Pichiorri F, Palumbo T, Iuliano R, Cimmino A, Aqeilan R, et al. MicroRNA fingerprints during human megakaryocytopoiesis. Proc Natl Acad Sci U S A (2006) 103:5078-83. doi:10.1073/pnas.0600587103

86. Undi RB, Kandi R, Gutti RK. MicroRNAs as haematopoiesis regulators. Adv Hematol (2013) 2013:695754. doi:10.1155/2013/695754

87. Ferracin M, Zagatti B, Rizzotto L, Cavazzini F, Veronese A, Ciccone M, et al. MicroRNAs involvement in fludarabine refractory chronic lymphocytic leukemia. Mol Cancer (2010) 9:123. doi:10.1186/1476-4598-9-123

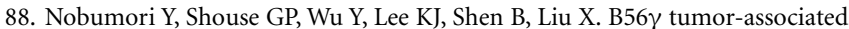
mutations provide new mechanisms for B56 $\gamma$-PP2A tumor suppressor activity. Mol Cancer Res (2013) 11:995-1003. doi:10.1158/1541-7786.MCR-12-0633

89. Garzon R, Volinia S, Liu CG, Fernandez-Cymering C, Palumbo T, Pichiorri F, et al. MicroRNA signatures associated with cytogenetics and prognosis in acute myeloid leukemia. Blood (2008) 111:3183-9. doi:10.1182/blood-200707-098749

90. Arnold HK, Sears RC. Protein phosphatase 2A regulatory subunit B56alpha associates with c-myc and negatively regulates c-myc accumulation. Mol Cell Biol (2006) 26:2832-44. doi:10.1128/MCB.26.7.2832-2844.2006

91. Arnold HK, Sears RC. A tumor suppressor role for PP2A-B56alpha through negative regulation of c-Myc and other key oncoproteins. Cancer Metastasis $\operatorname{Rev}(2008)$ 27:147-58. doi:10.1007/s10555-008-9128-9

92. Jurkovicova D, Magyerkova M, Kulcsar L, Krivjanska M, Krivjansky V, Gibadulinova A, et al. miR-155 as a diagnostic and prognostic marker in hematological and solid malignancies. Neoplasma (2014) 61:241-51. doi:10.4149/neo_ 2014_032

93. O'Connell RM, Zhao JL, Rao DS. MicroRNA function in myeloid biology. Blood (2011) 118:2960-9. doi:10.1182/blood-2011-03-291971

94. Lee DW, Futami M, Carroll M, Feng Y, Wang Z, Fernandez M, et al. Loss of SHIP-1 protein expression in high-risk myelodysplastic syndromes is associated with miR-210 and miR-155. Oncogene (2012) 31:4085-94. doi:10.1038/ onc.2011.579

95. Yoon BS, Jun EK, Park G, Jun Yoo S, Moon JH, Soon Baik C, et al. Optimal suppression of protein phosphatase $2 \mathrm{~A}$ activity is critical for maintenance of human embryonic stem cell self-renewal. Stem Cells (2010) 28:874-84. doi:10.1002/stem.412

96. Hoffman B, Amanullah A, Shafarenko M, Liebermann DA. The proto-oncogene c-myc in hematopoietic development and leukemogenesis. Oncogene (2002) 21:3414-21. doi:10.1038/sj.onc.1205400

97. Ren J, Jin P, Wang E, Marincola FM, Stroncek DF. MicroRNA and gene expression patterns in the differentiation of human embryonic stem cells. J Transl Med (2009) 7:20. doi:10.1186/1479-5876-7-20

98. Feng X, Wang Z, Fillmore R, Xi Y. miR-200, a new star miRNA in human cancer. Cancer Lett (2014) 344:166-73. doi:10.1016/j.canlet.2013.11.004

99. Huang HN, Chen SY, Hwang SM, Yu CC, Su MW, Mai W, et al. miR200c and GATA binding protein 4 regulate human embryonic stem cell renewal and differentiation. Stem Cell Res (2014) 12:338-53. doi:10.1016/j.scr. 2013.11.009

100. Neviani P, Harb JG, Oaks JJ, Santhanam R, Walker CJ, Ellis JJ, et al. PP2Aactivating drugs selectively eradicate TKI-resistant chronic myeloid leukemic stem cells. J Clin Invest (2013) 123:4144-57. doi:10.1172/JCI68951

101. He L, Thomson JM, Hemann MT, Hernando-Monge E, Mu D, Goodson S, et al. A microRNA polycistron as a potential human oncogene. Nature (2005) 435:828-33. doi:10.1038/nature03552 
102. Aguda BD, Kim Y, Piper-Hunter MG, Friedman A, Marsh CB. MicroRNA regulation of a cancer network: consequences of the feedback loops involving miR-17-92, E2F, and Myc. Proc Natl Acad Sci U S A (2008) 105:19678-83. doi:10.1073/pnas.0811166106

103. Kwanhian W, Lenze D, Alles J, Motsch N, Barth S, Döll C, et al. MicroRNA-142 is mutated in about $20 \%$ of diffuse large B-cell lymphoma. Cancer Med (2012) 1:141-55. doi:10.1002/cam4.29

104. Cancer Genome Atlas Research Network. Genomic and epigenomic landscapes of adult de novo acute myeloid leukemia. N Engl J Med (2013) 368:2059-74. doi:10.1056/NEJMoa1301689

105. Finnerty JR, Wang WX, Hébert SS, Wilfred BR, Mao G, Nelson PT. The miR15/107 group of microRNA genes: evolutionary biology, cellular functions, and roles in human diseases. J Mol Biol (2010) 402:491-509. doi:10.1016/j. jmb.2010.07.051

106. Xu T, Zhu Y, Xiong Y, Ge YY, Yun JP, Zhuang SM. MicroRNA-195 suppresses tumorigenicity and regulates G1/S transition of human hepatocellular carcinoma cells. Hepatology (2009) 50:113-21. doi:10.1002/hep.22919

107. Yongchun Z, Linwei T, Xicai W, Lianhua Y, Guangqiang Z, Ming Y, et al. MicroRNA-195 inhibits non-small cell lung cancer cell proliferation, migration and invasion by targeting MYB. Cancer Lett (2014) 347:65-74. doi:10. 1016/j.canlet.2014.01.019

108. Ding J, Huang S, Wang Y, Tian Q, Zha R, Shi H, et al. Genome-wide screening reveals that miR-195 targets the TNF- $\alpha / N F-\kappa B$ pathway by down-regulating
IкB kinase alpha and TAB3 in hepatocellular carcinoma. Hepatology (2013) 58:654-66. doi:10.1002/hep.26378

109. Díaz-Beyá M, Navarro A, Ferrer G, Díaz T, Gel B, Camós M, et al. Acute myeloid leukemia with translocation $(8 ; 16)(\mathrm{p} 11 ; \mathrm{p} 13)$ and MYST3-CREBBP rearrangement harbors a distinctive microRNA signature targeting RET proto-oncogene. Leukemia (2013) 27:595-603. doi:10.1038/leu.2012.278

Conflict of Interest Statement: The author declares that the research was conducted in the absence of any commercial or financial relationships that could be construed as a potential conflict of interest.

Received: 23 October 2014; accepted: 05 February 2015; published online: 20 February 2015.

Citation: Ruvolo PP (2015) The interplay between PP2A and microRNAs in leukemia. Front. Oncol. 5:43. doi: 10.3389/fonc.2015.00043

This article was submitted to Hematology Oncology, a section of the journal Frontiers in Oncology.

Copyright (C) 2015 Ruvolo. This is an open-access article distributed under the terms of the Creative Commons Attribution License (CC BY). The use, distribution or reproduction in other forums is permitted, provided the original author(s) or licensor are credited and that the original publication in this journal is cited, in accordance with accepted academic practice. No use, distribution or reproduction is permitted which does not comply with these terms. 